\title{
Differences of Rape Myth Acceptance between Genders: A Systematic Review
}

\author{
Wong Weng See ${ }^{1}$ \\ ${ }^{1}$ Department of Counselor Education and Counseling Psychology, \\ Universiti Putra Malaysia, Malaysia \\ wwsee28@hotmail.com
}

\begin{abstract}
Understanding the differences in rape myth acceptance between genders can help individuals to gain a better view about rape myth related intervention and reduce sexual assault cases. Based on a systematic review, this paper summarized the recent findings and discuss about the underlying reasons behind rape myth acceptance, from the perspective of cultural of gender. 10 studies were chosen and males showed higher rape myth acceptance than female. Traditional gender roles, stereotypical view of power between both genders and sexual objectification of female appeared to be the predictor of this difference. Nevertheless, the other predictors such as level of rejection to equality, education and knowledge about sexual related issues and occupation of an individual played a bigger role than gender in special occasions.
\end{abstract}

KEYWORDS: Rape myth acceptance, Gender, Systematic review

\subsection{INTRODUCTION}

It is defined by Lee and Jordan (2014) that sexual assault is either a violent or non-violent behaviour which represents unwilling sexual relationship. According to statistical report from Women's Aid Organization of Malaysia (2011), rape cases which happened in Malaysia from year 2000 to year 2007 had increased from 1217 to 3098 . Moreover, only $20 \%$ of rape cases were reported to the police in Malaysia (Yeo, 2017). Even though there were rape cases which are happening around Malaysia, it was mentioned that there were lower report rates when compared to the actual incidents (Woon, 2014). It is because some of the people accepted rape cultural as they did not think it was a serious issue. Some of the rape cases even happened in a family between the husband and the wife because the husband believed that it was not considered as a rape (Mokhtar, 2015). This kind of stereotyping views had prevented most sexual assault victims from reporting their cases to the authorities (Brown \& Campbell, 2010).

Some people in Malaysia think that depersonalizing an individual as a sexual object was fine, which can be seen in the case of IACT College and Brickfields Asia College students, who made rape jokes about women in a WhatsApp group (Azlan, 2017). The existence of rape cultural followed by the comment of a former sharia judge, Datuk Shabudin Yahaya, who said that rape victims who married the rapist could reduce social issues in Malaysia (Lamb, 2017). He also made a comment that a 12-yearold child is well prepared for marriage, in both physical and mental. The rape cultural in Malaysia provides no justice for the rape victims, it even protects the rape perpetrator or rapist to continue and violate the safety of their targets. Both of these incidents pointed out males accept rape cultural more than female, and treat rape myth as a norm.

Burt (1980) defined rape myths as "prejudicial, stereotyped, or false beliefs about rape, rape victims, and rapists". It is a stereotypical view of a person towards rape behavior, sex offenders and the victims of rape. A study showed that those who had higher acceptance in rape myths would have higher chances of performing rape (Foubert, Brosi, \& Bannon, 2011). The acceptance of rape myth would affect the likelihood of helping the rape victims as it is proved by an experiment study of bystander behavior (Banyard, Plante, \& Moynihan, 2004). If a person had less acceptance of rape myth, which they believed that the rape victim was not to be blamed in the situation, they would help the victim. Thus, rape myth acceptance does not only influence the possibility of performing sexual assault, it also reduces the chance for one to help the rape victims. Some studies have shown differences in gender regarding to rape myth acceptance. A study of Mori, Bernat, Glenn, Selle and Zarate (1995) suggested that males having higher rape myth acceptance than females. A more recent study of Davies, Gilston and Rogers (2012) also supported that males portrayed more negative attitudes of rape myths than females. The underlying reasons of the difference in rape myth acceptance between both genders are intriguing. By understanding the differences and the cultural behind both genders, one can generate a 
better prevention system in order to reduce rape myth. By examining the reason of causing gender differences in rape myth acceptance, one can effectively reduce the cases of rape and encourage the helping behaviour towards rape victims.

\subsection{Objective}

The aim of this review is to find out the differences in rape myth acceptance between both genders. Gender difference acts as a cultural, which plays an important role to understand rape myth acceptance between male and female. Various factors which influenced rape myth acceptance are expected to be found. The cultural differences will be examined systematically in order to answer the following objective:

1. To investigate the findings related to rape myth acceptance in both genders from year 20132017.

The first objective is to examine the finding of each literature, which is the final result in each study. As every selected literature is conducted in quantitative research, statistical test was used to analyze hypotheses in order to generalize the result to the larger population (Fraenkel, Wallen \& Hyun, 2016). Thus, it is important to compare and contrast the findings of the literature, to see whether the results are generalizable into both genders.

2. To investigate the reasons of the differences in acceptance of rape myth between male and female.

The next objective is to find out the reason behind the differences in acceptance of rape myth between both genders. The reasons will be compared and discuss if there is or there is not a differences in rape myth acceptance between male and female.

\subsection{METHOD}

The main keywords, which are rape myth and gender, were entered for starting the systematic review into the search engine. The author's biases can be reduced if a systematic review is used as it is a step by step analysis that helps one to formulate the results of the findings. By following the objectives stated in the study, the author selected the suitable researches to produce a systematic review about rape myth between both genders. Systematic review can help the researcher to minimize the bias so that well-grounded results can be generated to complete the research objectives.

\subsection{The Search Strategy}

SCOPUS database was used to search for literatures. The keywords to enter were rape myth and gender, so a diverse amount of literatures were found to be selected later. Next, the inclusion and exclusion criteria were added in to the searching process, as shown in Tables 1 and 2. Only literatures from year 2013 to 2017 were retrieved. Moreover, the main subject area chosen was social science in the SCOPUS database. Moreover, inclusive language was selected as English to effectively search for literature later. The details are shown in Table 1.

Table 1. Inclusion Criteria of the Systematic Review

\begin{tabular}{llcc}
\hline $\begin{array}{c}\text { Inclusion Criteria } \\
\text { Presented in Order }\end{array}$ & \multicolumn{1}{c}{ Particulars } & $\begin{array}{c}\text { Literatures } \\
\text { Identified }\end{array}$ & $\begin{array}{c}\text { Remaining } \\
\text { Literatures }\end{array}$ \\
\hline Key terms & Rape myth and gender & 222 & 222 \\
Year & 2013-2017 & 80 & 80 \\
Subject area & Social science & 48 & 48 \\
Language & English & 48 & 48 \\
\hline
\end{tabular}

Table 2. Exclusion Criteria of the Systematic Review

\begin{tabular}{|c|c|c|c|}
\hline $\begin{array}{l}\text { Exclusion Criteria } \\
\text { Presented in Order }\end{array}$ & llars & $\begin{array}{l}\text { Literatures } \\
\text { Identified }\end{array}$ & Literatures \\
\hline
\end{tabular}




\begin{tabular}{llcc}
\hline Inclusion criteria & & 48 & 48 \\
Article type & Article in press & 3 & 45 \\
Journal source & Review & 2 & 43 \\
& Journal of Criminal Psychology & 1 & \\
& Sexuality and Cultural & 3 & \\
& Sex Roles & 1 & \\
& SAGE Open & 1 & \\
& Social Justice Research & 1 & 10 \\
\hline Social Science Quarterly & 1 & \\
& Military Psychology & 1 & \\
& Feminist Criminology & 1 & \\
& Total & 10 & \\
\hline
\end{tabular}

\subsection{Inclusion criteria}

All literatures consisted of the keywords of rape myth and gender and were published within the year of 2013 to 2017. The articles were chosen from the subject area of social science and were written in English language.

\subsection{Exclusion criteria}

Studies which were articles in press and reviews were excluded. The final literatures were selected from the journal sources listed in Table 2.

\subsection{RESULTS}

\subsection{Systematic review process}

The highest numbers of journals, which are 222 relevant journals, were found using the keywords. The number gradually decreased when the inclusion and exclusion criteria were added. The researcher ended the search when the journals were identified and selected in the database. The selected journals were saved in Adobe pdf (Version 3) format. Table 3 was constructed as every journal was studied and reviewed.

222 journals were found by the use of keywords initially and 80 journals from year 2013 to 2017 were chosen. Then, the subject of social science was added as inclusion criteria and 48 journals were chosen. These 48 journals remain as English language was added as another inclusion criterion.

After that, the journals were excluded from article in press and review, and 43 journals were selected. Finally, 10 journals were selected from the certain journal source listed in Table 2 . All selected journals are summarized in Table 3.

\subsection{Study findings}

In total, 8 of 10 journals were published in United States, one journal was from United Kingdom and one journal was from Serbia. All the studies were conducted quantitatively. 6525 participants were involved in these studies and 4267 of them were males whereas 2258 of them were females. The findings are presented in Table 4.

Table 3. Summary of Selected Literatures

\begin{tabular}{lllll}
\hline \multicolumn{1}{c}{ Author (Year) } & \multicolumn{1}{c}{ Title of the Article } & Country & \multicolumn{1}{c}{ Sample } & \multicolumn{1}{c}{ Objectives } \\
\hline Barnett, M.D., & Masculinity, Femininity, & United & Heterosexual & The study examines \\
Hale, T.M., \& & Sexual Dysfunctional & States & college men & beliefs about sexuality \\
Sligar, K.B. & Beliefs, and Rape Myth & & and women: & and gender roles with the \\
(2017) & Acceptance Among & & 840 & connection of rape myth \\
& Heterosexual College & & Male: 230 & acceptance. \\
\hline
\end{tabular}




\begin{tabular}{|c|c|c|c|c|}
\hline & Men and Women & & Female: 610 & \\
\hline $\begin{array}{l}\text { Emmers- } \\
\text { Sommer, T. } \\
(2014)\end{array}$ & $\begin{array}{l}\text { Adversarial Sexual } \\
\text { Attitudes Toward } \\
\text { Women: The } \\
\text { Relationships with } \\
\text { Gender and } \\
\text { Traditionalism }\end{array}$ & $\begin{array}{l}\text { United } \\
\text { States }\end{array}$ & $\begin{array}{l}\text { Male: } 342 \\
\text { Female: } 375\end{array}$ & $\begin{array}{l}\text { The study examines } \\
\text { gender differences in } \\
\text { adversarial attitudes } \\
\text { towards women and their } \\
\text { relationships with } \\
\text { traditionalism and age. }\end{array}$ \\
\hline $\begin{array}{l}\text { Papp, L. J., \& } \\
\text { Erchull, M. J. } \\
(2017)\end{array}$ & $\begin{array}{l}\text { Objectification and } \\
\text { System Justification } \\
\text { Impact Rape Avoidance } \\
\text { Behavior }\end{array}$ & $\begin{array}{l}\text { United } \\
\text { States }\end{array}$ & Female: 294 & $\begin{array}{l}\text { Participants were } \\
\text { surveyed for experiences } \\
\text { of objectification, belief } \\
\text { in a just world, gender- } \\
\text { specific system } \\
\text { justification, benevolent } \\
\text { sexism, rape myth } \\
\text { acceptance, and } \\
\text { engagement in rape } \\
\text { avoidance behaviours. }\end{array}$ \\
\hline $\begin{array}{l}\text { Stephens, T., } \\
\text { Kamimura, A., } \\
\text { Yamawaki, N., } \\
\text { Bhattacharya, } \\
\text { H., Mo, W., } \\
\text { Birkholz, R., } \\
\text { Makomenaw, } \\
\text { A., \& Olson, } \\
\text { L.M. (2016) }\end{array}$ & $\begin{array}{l}\text { Rape Myth Acceptance } \\
\text { Among College Students } \\
\text { in the United States, } \\
\text { Japan, and India }\end{array}$ & $\begin{array}{l}\text { United } \\
\text { States }\end{array}$ & $\begin{array}{l}\text { U.S., Male: } 90 \\
\text { Female: } 116 \\
\text { Japan, Male: } \\
102 \\
\text { Female: } 113 \\
\text { India, Male: } \\
65 \\
\text { Female: } 151\end{array}$ & $\begin{array}{l}\text { The study examines } \\
\text { relationship of country } \\
\text { and gender differences in } \\
\text { rape myth acceptance } \\
\text { among undergraduate } \\
\text { students in the United } \\
\text { States, Japan, and India. }\end{array}$ \\
\hline $\begin{array}{l}\text { Carroll, M.H., } \\
\text { Rosenstein, J.E., } \\
\text { Foubert, J.D., } \\
\text { Clark, M.D., \& } \\
\text { Korenman, L.M. } \\
(2016)\end{array}$ & $\begin{array}{l}\text { Rape Myth Acceptance: } \\
\text { A Comparison of } \\
\text { Military Service } \\
\text { Academy and Civilian } \\
\text { Fraternity and Sorority } \\
\text { Students }\end{array}$ & $\begin{array}{l}\text { United } \\
\text { States }\end{array}$ & $\begin{array}{l}\text { U.S. Military } \\
\text { Academy, } \\
\text { Male: } 1003 \\
\text { Female: } 166 \\
\text { Midwestern } \\
\text { university, } \\
\text { Male: } 1551 \\
\text { Female: } 365\end{array}$ & $\begin{array}{l}\text { The study examines } \\
\text { differences of rape myth } \\
\text { acceptance among } \\
\text { participants from the } \\
\text { military and fraternities. }\end{array}$ \\
\hline $\begin{array}{l}\text { Borinca, I. } \\
(2016)\end{array}$ & $\begin{array}{l}\text { Social Exclusion and } \\
\text { Sexual Objectification } \\
\text { Among 18- to } 30 \text {-Year- } \\
\text { Old Men in Kosovo }\end{array}$ & Serbia & Male: 94 & $\begin{array}{l}\text { The study examines the } \\
\text { relationship between } \\
\text { sexual objectification of } \\
\text { female and rape myth } \\
\text { acceptance among male } \\
\text { participants. }\end{array}$ \\
\hline $\begin{array}{l}\text { Duff, S., \& } \\
\text { Tostevin, A. } \\
(2015)\end{array}$ & $\begin{array}{l}\text { Effects of gender, rape } \\
\text { myth acceptance, and } \\
\text { perpetrator occupation } \\
\text { on perceptions of rape }\end{array}$ & $\begin{array}{l}\text { United } \\
\text { Kingdom }\end{array}$ & $\begin{array}{l}\text { Male: } 65 \\
\text { Female: } 120\end{array}$ & $\begin{array}{l}\text { The study examines the } \\
\text { relationship of } \\
\text { participant's gender, } \\
\text { perpetrator occupation } \\
\text { and rape myth } \\
\text { acceptance with attitude } \\
\text { towards rape victims. }\end{array}$ \\
\hline Farris, E.M., \& & Public Officials and a & United & Male: 548 & This article investigates \\
\hline
\end{tabular}




\begin{tabular}{|c|c|c|c|c|}
\hline $\begin{array}{l}\text { Holman, M.R. } \\
\text { (2015) }\end{array}$ & $\begin{array}{l}\text { "Private" Matter: } \\
\text { Attitudes and Policies in } \\
\text { the County Sheriff } \\
\text { Office Regarding } \\
\text { Violence Against } \\
\text { Women }\end{array}$ & States & Female: 5 & $\begin{array}{l}\text { the relationship of } \\
\text { sheriff's attitudes, } \\
\text { office's policies and rape } \\
\text { myth acceptance. }\end{array}$ \\
\hline $\begin{array}{l}\text { Hayes, R.M., } \\
\text { Lorenz, K., \& } \\
\text { Bell, K.A. } \\
(2013)\end{array}$ & $\begin{array}{l}\text { Victim Blaming Others: } \\
\text { Rape Myth Acceptance } \\
\text { and the Just World } \\
\text { Belief }\end{array}$ & $\begin{array}{l}\text { United } \\
\text { States }\end{array}$ & $\begin{array}{l}\text { Male: } 110 \\
\text { Female: } 241\end{array}$ & $\begin{array}{l}\text { The study interested in } \\
\text { finding the gender } \\
\text { difference in rape myth } \\
\text { acceptance. }\end{array}$ \\
\hline $\begin{array}{l}\text { Chapleau, K.M., } \\
\text { \& Oswald, D.L. } \\
\text { (2013) }\end{array}$ & $\begin{array}{l}\text { Status, Threat, and } \\
\text { Stereotypes: } \\
\text { Understanding the } \\
\text { Function of Rape Myth } \\
\text { Acceptance }\end{array}$ & $\begin{array}{l}\text { United } \\
\text { States }\end{array}$ & $\begin{array}{l}\text { Male: } 67 \\
\text { Female: } 102\end{array}$ & $\begin{array}{l}\text { The study finds out } \\
\text { relationship of gender } \\
\text { differences, rejection to } \\
\text { equality and rape myth } \\
\text { acceptance. }\end{array}$ \\
\hline
\end{tabular}

Table 4. Findings of selected journal articles

\begin{tabular}{lll}
\hline No. & \multicolumn{1}{c}{ Author (Year) } & \multicolumn{1}{c}{ Relevant findings } \\
\hline 1 & Barnett, M.D., Hale, T.M., \& & Both male and female sexual dysfunctional beliefs were \\
& Sligar, K.B. (2017) & $\begin{array}{l}\text { positively associated with rape myth acceptance. Gender } \\
\text { roles did not have relationship with rape myth acceptance } \\
\end{array}$ \\
& & $\begin{array}{l}\text { among males, whereas femininity was negatively correlated } \\
\text { with rape myth acceptance. }\end{array}$
\end{tabular}

2 Emmers-Sommer, T. (2014) Males have higher rape myth acceptance, adversarial sexual beliefs and interpersonal violence than females.

3 Papp, L. J., \& Erchull, M. J. Experiences of sexual objectification and system justification (2017) constructs were significantly positively correlated with rape myth acceptance.

4 Stephens, T., Kamimura, A., U.S. participants were less likely to believe in rape myths, Yamawaki, N., Bhattacharya, followed by Japan and India.

H., Mo, W., Birkholz, R., Makomenaw, A., \& Olson, Females showed lower rape myth acceptance in general.

L.M. (2016)

5 Carroll, M.H., Rosenstein, J.E., Foubert, J.D., Clark, M.D., \& Korenman, L.M (2016)

6 Borinca, I. (2016)

Male showed higher level of rape myth acceptance compared to female.

7 Duff, S., \& Tostevin, A. (2015)

Sexual objectification of female was not related to rape myth acceptance among male participants.

Participant's occupation and rape myth acceptance, regardless of gender, were related to attitude towards rape victims.

8 Farris, E.M., \& Holman, M.R. Sheriffs who had high rape myth acceptance would have (2015) negative attitude towards violence against women. 


\begin{tabular}{lll}
\hline 9 & $\begin{array}{l}\text { Hayes, R.M., Lorenz, K., \& } \\
\text { Bell, K.A. (2013) }\end{array}$ & Male accept rape myths more than female. \\
10 & $\begin{array}{l}\text { Chapleau, K.M., \& Oswald, } \\
\text { D.L. (2013) }\end{array}$ & $\begin{array}{l}\text { Rape myth acceptance was affected by one's rejection to } \\
\text { equality, and the status of victim and perpetrator. }\end{array}$ \\
\hline
\end{tabular}

\section{DISCUSSION AND IMPLICATION}

Sexual dysfunctional beliefs play a larger role when compared to self-perceived masculinity and femininity regarding to relationship with rape myth acceptance (Barnett, Hale, \& Sligar, 2017). One's own stereotype about sexuality and traditional gender roles is positively related to rape myth acceptance. If a society endorses more traditional biases, those who are living in such cultural will have higher chance to accept rape myth. The society will tend to blame the rape victims and disregard their trauma by making rape cases a norm.

The study of Emmers-Sommer (2014) stated that our world is guided by traditional sexual scripts despite of our education, profession or social economic status. Males generally are given more power in sexual relationship whereas females are treated as less active. Thus, some might blame females for allowing the sexual intercourse to become rape as the females did not fight back. This is supported in the study of Carroll, Rosenstein, Foubert, Clark and Korenman (2016), as males also reported a higher rape myth acceptance than females. The related rape myths were denial of male rapist's responsibility, females who drink alcohol and dress inappropriate are responsible for the rape cases and beliefs that women lied about being rape.

Other than that, the study of Hayes, Lorenz and Bell (2013) also showed that males had higher rape myth acceptance when compared to females. Males typically receive more power in the gender role, therefore create a false vision that females are weaker and can be blamed for when rape cases happened. The women are more passive in a sexual relationship when compared to men, who are more aggressive, thus are blamed for not rejecting the sexual intercourse. Even if the female rejected, it was considered as not truthful or not genuine.

However, females who encountered more sexual objectification will show higher rape myth acceptance as it makes them feel safer (Papp, \& Erchull, 2017). She projected her fear for being sexually assaulted to others, thus reported a higher beliefs in rape myth. System justification also plays in explaining higher acceptance of rape myth among females as it is a way to convince oneself that although one situation can have negative impact, it can still produce positive result for one's society position. By projecting one's fear when being sexually objectified, one feel less threatened in their cultural. Thus, if a cultural often sexually objectifies females, rape myth acceptance may be higher within the particular cultural. As blaming the rape victims is socially accepted and it serves as a norm in one circumstance, females may report higher beliefs in rape myths in order to protect themselves from society's discrimination.

There is another study which proposed that sexual objectification of female did not have relationship with rape myth acceptance among male participants (Borinca. 2016). The study showed that if the male was emotionally sensitive in a romantic relationship, they perceived women as a human being rather than an object. Males who were sensitive in romantic relationship tend to pay more attention to their partner, as they wanted their relationship to be safe. Thus, this category of males was less likely to sexually objectified women and showed less rape myth acceptance. It suggested among the selected population, personal experience and personality is more important than environmental effect when one perceives beliefs in rape myth. However, this study only used the sample of Kosovo male, so there was no comparison between genders.

Another study which used 99 percent of male participants showed those who had more negative attitude towards violence against women would also report higher result in rape myth acceptance (Farris and Holman, 2015). This study showed its significance as it was done in the population of U. S. sheriff, who were the main force when dealing with everyday domestic violence. It also found that those who believe in rape myths tend to receive less education or training related to sexual assault's issues. Thus, the study suggested that the possible reason of high rape myth acceptance among sheriffs was the lack 
of knowledge about the related policies.

Moreover, a study showed rape myth acceptance differs among three countries, which were United States, Japan and India (Stephens, Kamimura, Yamawaki, Bhattacharya, Mo, Birkholz, Makomenaw, \& Olson, 2016). Participants from U. S. showed lower rape myth acceptance, and followed by participants from Japan and India. One of the reasons behind the difference is students from U. S. received adequate education regarding to sexual discrimination from schools. Title IX is a type of model used for educating students about sexual assaults, thus they understand the effect and misconception of rape myth. When compared, participants from Japan and India had less knowledge regarding sexual assaults or rape myths. The study also suggested that those who have less knowledge about community or organization for sexual assault prevention would report higher rape myth acceptance. Overall, this study stated that education and knowledge within a cultural can influence one's beliefs in rape myth.

The study from Duff and Tostevin (2015) however showed that one's occupation had a greater impact rather than gender in relation to attitudes to rape victims and rape myth acceptance. The perception of oneself was related to one's attitude more than how he or she recognized with the perpetrator of the rape case. There is no relationship between one's occupation and the rapist's occupation in relation to rape myth acceptance or attitude towards rape victims. For example, if a rapist is male, it is not necessary for a male observer to have negative attitude towards rape victims or reported higher rape myth acceptance. On the other hand, one from the helping profession such as social worker who has more sexual assault related knowledge, may have lower rape myth acceptance regardless of gender.

Moreover, one's rejection to equality in the society, as one oppose changes in traditional cultural in order to protect themselves, was positively related to rape myth acceptance. Participants who had higher rejection to equality showed higher rape myth acceptance, when the victims was at low status and the perpetrator was at high status in society. For example, people with higher rejection to equality could not believe that a doctor would rape a prostitute, therefore would defend the high-status rapist. This situation applied for both males and females. However, for male who had lower rejection to equality, he would believe that the rapist should get punishment for the crime, without considering the status of the rapist. Female with lower rejection to equality on the other hand, would only had the similar belief if the perpetrator was higher status than the rape victim.

Overall, there is a gender difference in rape myth acceptance, as male generally reported higher rape myth acceptance than female. The differences occur due to traditional gender roles, stereotypical view of power between both genders and sexual objectification of female. However, under certain circumstance, gender becomes less significant than other predictors such as level of rejection to equality, education and knowledge about sexual related issues and occupation of an individual.

The underlying reasons which cause the differences of gender in rape myth acceptance are discussed. Although intervention can be done accordingly to these reasons, it is undeniable that males need more sexual related education when compared to females. Changing one's traditional gender role values is a challenge, but this is a worthy effort to be made for living in a better and safer environment. Gender serves as a cultural for one to better understand rape myths, as the society expects one to behave in certain ways. The traditional gender roles therefore produce stereotypes and then related to rape myth acceptance. The impact of rape myths can be reduce if one is taught with adequate knowledge, and trained to provide suitable help to the victims. The prevalence of rape cases might also decrease as the society understand the harmfulness of rape myth acceptance, therefore stop threating such crime as a norm. The education field can teach students about sexual related knowledge, to increase their awareness and reduce beliefs in rape myths.

The limitation of this study is that most of the selected studies were from United States. Thus, the analysis is more western orientated. Moreover, only 10 journals were selected for this study. The further study is suggested to include journals from other countries, and review more journals to collect more information. Other than gender, additional cultural influences can be discussed and included in the further study. Qualitative research can help to interpret the differences in a more culturally precise way as it focuses on individual experience. Thus, more research including qualitative research is encouraged to be conducted in several different countries. 


\section{CONCLUSION}

Based on the discussion above, one can understand that in general, male reported higher rape myth acceptance than female. Traditional gender role which form the norm of society and self-concept of a person plays an importance role to explain the differences. Next, as the power of male is traditionally higher than female, the female often become the person to be blame in a rape case, for not being genuine to reject the sexual intercourse. Also, sexual objectification of female causes women to have high beliefs in rape myth, as they do not want to be judge by the society norm.

Nevertheless, gender is only one of the predictor of rape myth acceptance, as more related variables surface when more complicated studies were done. Level of rejection to equality, education and knowledge about sexual related issues and occupation became more dominant than the effect of gender when examined with rape myth acceptance. Therefore, more research is encouraged to be conducted especially in Asian countries where rape is often seemed as a taboo and rarely been discussed.

\section{REFERENCES}

Azlan, H. (2017, April 12). Malaysian college students make rape comments, netizens deny rape culture. Retrieved from http://www.thelevel.my/netizens-deny-rape-culture/

Banyard, V. L., Plante, E. G., \& Moynihan, M. M. (2005). Rape prevention through bystander education: Final report to NIJ for grant 2002-WG-BX-0009. Retrieved from www.ncjrs.org0pdffiles10nij0grants0208701.pdf

Barnett, M.D., Hale, T.M., \& Sligar, K.B. (2017). Masculinity, femininity, sexualdysfunctional beliefs, and rape myth acceptance among heterosexual college men and women. Sexuality \& Culture,

$$
21,741-753 \text {. }
$$

Borinca, I. (2016). Social exclusion and sexual objectification among 18- to 30-year-old men in Kosovo. $\quad$ Sexuality \& Culture, 20, 684-698.

Burt, M. (1980). Cultural myths and supports for rape. Journal of Personality \& Social Psychology, $38(2), 217-230$.

Carroll, M.H., Rosenstein, J.E., Foubert, J.D., Clark, M.D., \& Korenman, L.M. (2016). Rape myth acceptance: A comparison of military service academy and civilian fraternity and sorority students. Military Psychology, 1-12.

Chapleau, K.M., \& Oswald, D.L. (2013). Status, threat, and stereotypes: Understanding the function of rape myth acceptance. Social Justice Research, 26, 18-41.

Davies, M., Gilston, J., \& Rogers, P. (2012). Examining the relationship between male rape myth acceptance, female rape myth acceptance, victim blame, homophobia, gender roles, and ambivalent sexism. Journal of Interpersonal Violence, 27(14), 2807-2823.

Duff, S., \& Tostevin, A. (2015). Effects of gender, rape myth acceptance, and perpetrator occupation on perceptions of rape. Journal of Criminal Psychology, 5(4), 249-261.

Emmers-Sommer, T. (2014). Adversarial sexual attitudes toward women: The relationships with gender and traditionalism. Sexuality \& Culture, 18, 804-817.

Farris, E.M., \& Holman, M.R. (2015). Public officials and a "private" matter: Attitudes and policies in the county sheriff office regarding violence against women. Social Science Quarterly, 98(4), 1117-1135.

Foubert, J. D., Brosi, M. W., \& Bannon, R. S. (2011). Pornography viewing among fraternity men: Effects of bystander intervention, rape myth acceptance, and behavioral intent to commit sexual assault. Sexual Addiction and Compulsivity, 18(4), 212-231.

Fraenkel, J. R., Wallen, N. E., \& Hyun, H. H. (2016). How to design and evaluate research in education (9th ed.). New York: McGraw-Hill Education.

Hayes, R.M., Lorenz, K., \& Bell, K.A. (2013). Victim blaming others: Rape myth acceptance and the just world belief. Feminist Criminology, 8(3), 202-220.

Lamb, K. (2017). Rape victims should marry their rapists, Malaysian MP tells parliament. Retrieved from https://www.theguardian.com/world/2017/apr/05/victims-should- marrytheir- rapists-malaysian-mp-tells-parliament

Lee, R. \& Jordan, J. (2014). Crisis assessment, intervention, and prevention (2nd ed.). Boston, 
MA: Pearson.

Mokhtar, R. H. (2015, May 6). Debunking marital rape myth. The Malaysian Insider. Retrieved from http://www.themalaysianinsider.com/sideviews/article/debunking-marital-rape-mythrafidah-hanim-mokhtar

Mori, L., Bernat, J. A., Glenn, P. A., Selle, L. L., \& Zarate, M. G. (1995). Attitudes toward rape: Gender and ethnic differences across Asian and Caucasian college students. Sex Roles, 32(7-8), 457-467.

Papp, L. J., \& Erchull, M. J. (2017). Objectification and system justification impact rape avoidance behavior. Sex Roles, 76, 110-120.

Stephens, T., Kamimura, A., Yamawaki, N., Bhattacharya, H., Mo, W., Birkholz, R., Makomenaw, A., \& Olson, L.M. (2016). Rape myth acceptance among college students in the United States, Japan, and India. SAGE Open, 1-8.

Woon, L. (2014, March 18). Malays more offended by rape, Dewan told. FMT News. Retrieved from http://www.freemalaysiatoday.com/category/nation/2014/03/18/malays-moreoffended-by- rape-dewan-told/

Yeo, B. Y. (2017, April 13). Patriarchy and the rape culture in Malaysia. Retrieved from http://www.malaysiakini.com/news/378991 